\title{
DRY MATTER DECOMPOSITION OF COVER CROPS IN A NO-TILLAGE COTTON SYSTEM ${ }^{1}$
}

\author{
JOÃO LUÍS DA SILVA FILHO², ANA LUÍZA DIAS COELHO BORIN ${ }^{2 *}$, ALEXANDRE CUNHA DE BARCELLOS \\ FERREIRA ${ }^{2}$
}

\begin{abstract}
No-tillage cotton systems require soil coverage with cover crop residue for a longer time due to the late cycle of cotton. However, decomposition rates may vary between cover crops, and the adjustment of models to describe it is critical to no-tillage cotton management. Two non-linear regression models, exponential (EM) and Michaelis-Menten (MM), were adjusted to dry matter decomposition of cover crops in a cotton no-tillage system, in Brazil. Three field trials were performed in 2012 for the cover crops Urochloa ruziziensis (brachiaria), Pennisetum glaucum (pearl millet), and Cajanus cajan (pigeon pea). Samples of cover crop were collected at $20,50,70,110,140$, and 170 days after sowing upland cotton to measure dry matter decomposition. MM showed better adjustment than EM for all cover crops. The estimations of half-life parameters were different between the cover crops, suggesting that each cover crop has its own rate of decomposition. For pearl millet, brachiaria, and pigeon pea, the half-life estimation by exponential model was over the MM in 9, 12, and 12 days.
\end{abstract}

Keywords: Exponential model. Michaelis-Menten. Gossypium hirsutum. No-tillage.

\section{DECOMPOSIÇÃO DE MATÉRIA SECA DE PLANTAS DE COBERTURA NA SEMEADURA DIRETA DO ALGODOEIRO}

\begin{abstract}
RESUMO - Para a semeadura direta é preciso adequada quantidade de palha sobre o solo, e devido ao longo ciclo do algodoeiro, sua persistência deve ser alta. Entretanto, como a decomposição dos resíduos vegetais ao longo do tempo pode variar entre as plantas de cobertura, o ajuste de modelos que melhor a descreva é essencial. Dois modelos de regressão não-linear, exponencial (ME) e Michaelis-Menten (MM), foram ajustados à decomposição de matéria seca de plantas de cobertura no sistema de semeadura direta do algodoeiro, em condições do Cerrado goiano. Três experimentos foram instalados no ano de 2012, cada um consistido de uma espécie de planta de cobertura, sendo Urochloa ruziziensis (braquiária ruziziensis), Pennisetum glaucum (milheto) e Cajanus cajan (guandu). Em cada ensaio, procedeu-se a amostragem da palha da planta de cobertura aos 20,50,70,110,140 e 170 dias após a semeadura do algodoeiro, para determinação da matéria seca remanescente. Para as três plantas de cobertura o modelo MM apresentou melhor ajuste que o ME. As estimativas dos tempos de meia-vida das palhadas via MM diferiram entre as plantas de cobertura, indicando que cada uma possui velocidade de decomposição específica. Para o milheto, o guandu e a braquiária, as estimativas de tempo de meia-vida pelo ME foram superiores às do MM em 9, 12 e 12 dias, respectivamente.
\end{abstract}

Palavras-chave: Modelo exponencial. Michaelis-Menten. Gossypium hirsutum. Plantio direto.

\footnotetext{
${ }^{\text {"Corresponding author }}$

${ }^{1}$ Received for publication in 07/18/2016; accepted in 06/28/2017

${ }^{2}$ Embrapa Algodão, Campina Grande, PB, Brazil; joao.silva-filho@embrapa.br, ana.borin@embrapa.br, alexandrecunha.ferreira@embrapa.br.
} 


\section{INTRODUCTION}

The success of agriculture in the Brazilian "Cerrado" occurred parallel to the increased adoption of the no-tillage system. To ensure permanent soil cover for direct seeding of the cotton in that biome, some research has been conducted with cover crops (FERREIRA et al., 2010; FERREIRA et al., 2012), as the plant residues of the main crop provide little contribution to soil coverage and protection.

The dynamics of plant residue decomposition depends on residue chemical composition, the amount of matter, and the soil and climate conditions (ESPÍNDOLA et al., 2006). In tropical regions, decomposition is accelerated when compared to temperate climate regions. For this reason, it is important to grow plants with high production of dry matter (DM) to offset the rapid decomposition (DERPSCH et al., 2010).

The cover crops Urochloa ruziziensis (brachiaria or ruzi grass ) and Pennisetum glaucum (millet) are frequently used in the Brazilian "Cerrado" (PACHECO et al., 2011), due to the high production of $\mathrm{DM}$ with a high $\mathrm{C} / \mathrm{N}$ ratio, a feature that provides high persistence and soil protection; in addition, they adapt easily and are also easy to plant and cultivate. Other species, such as the legume Cajanus cajan (pigeon pea), with a semi-perennial habit and good tolerance to higher temperatures and water deficit typical conditions of the inter-crop period in the "Cerrado," can produce large amounts of DM and increase nitrogen in the soil by biological fixation.

The exponential model has been one of the most used to describe the decomposition of plant residues over time (BOER et al., 2008; PACHECO et al., 2011; SORATTO et al., 2012; ROSSI et al., 2013; ACOSTA et al., 2014; COSTA et al., 2014; COSTA et al., 2015). In this model, the estimate of the decomposition parameter has a difficult interpretation in itself and additional calculations are required to obtain useful information, such as the time required for half of the residue to decompose.

On the other hand, if the decomposed portion is used as a response variable instead of the remaining portion of plant residues, other models become potentially interesting, such as the Michaelis-Menten model, in which a parameter is estimated that can be directly interpreted as the half-life of decomposition. This model is very frequently used for the description of the kinetics of chemical reactions (SORENSEN; NOVAK, 1996), reactions catalyzed by enzymes, theoretical descriptions of the enzymatic mechanisms (MACHADO, 2006), and the release of nutrients into the soil (ZEVIANI et al., 2012).

Due to the existence of some options of cover crops for the "Cerrado" biome, the models that best explain decomposition may vary among cover crops, and even though those end up having the same parameterization, we still need to make sure the estimates differ between species. Tests for nonlinear models have already been proposed according to the experimental guidelines of randomized complete block designs (REGAZZI; SILVA, 2004; REGAZZI; SILVA, 2010).

The purpose of this work was to compare adjustments to the exponential and MichaelisMenten models to dry matter decomposition of Urochloa ruziziensis, Pennisetum glaucum, and Cajanus cajan, used as cover species in the direct-seeding system of cotton.

\section{MATERIAL AND METHODS}

Three trial fields were installed in the year 2012, in Red Latosol soil, at Santa Helena de Goiás, GO, Brazil, at an altitude of $560 \mathrm{~m}$. The climate of the region is of the Aw type (Köppen classification) with average annual precipitation in the years 2012 and 2013 of 1,488 mm, generally occurring between November and March. The annual average temperature during the two years of the trial was $25.1^{\circ} \mathrm{C}$, and the minimum and maximum averages were $19.1^{\circ} \mathrm{C}$ and $31.1^{\circ} \mathrm{C}$, respectively. Each field trial consisted of one species of cover plant, namely Urochloa ruziziensis (brachiaria), Pennisetum glaucum (millet), or Cajanus cajan (pigeon pea), seeded after the harvest of soybeans, and preceding the cultivation of cotton. Each cover crop was represented by four large fields of $100 \mathrm{~m}^{2}$ (blocks), and the treatments were the times $(20,50,70,110$, 140 , and 170 days after the sowing of cotton - DAS) at which straw dry matter was measured. Thus, each field trial was designed in random blocks with six treatments and four replications.

After the harvest of soybeans, the soil was mechanically grooved with $0.45 \mathrm{~m}$ spacing between lines, and the species were sown by hand on March 5, 2012, without adding fertilizer. For sowing, we used 8,15 , and $25 \mathrm{~kg} \mathrm{ha}^{-1}$ of seeds of brachiaria (pure live seed of 75\%), millet (BRS 1501), and pigeon pea (BRS Mandarin), respectively. The fields were not irrigated, and no control of weeds, pests, and diseases was used.

Three samples of green plants, in an area of $0.25 \mathrm{~m}^{2}$, were collected at random from each plot (field of $100 \mathrm{~m}^{2}$ ) on November 28, 2012, 20 days before the sowing of cotton. Samples of cover plants were placed separately in paper bags and taken to dry in an oven at a temperature of $65^{\circ} \mathrm{C}$ until the mass of dried plants reached a constant value.

Immediately after the last collection, the desiccation of cover plants was carried out with the herbicide glyphosate, at a dose of $1,440 \mathrm{~g} \mathrm{ha}^{-1}$ of the active ingredient. On December 15, 2012, a crusher of culture residues was used, at a height of $0.15 \mathrm{~m}$, to make the sowing of the cotton easier.

To assess the dynamics of the decomposition 
of plant residues, samples of $40 \mathrm{~g}$ of dry matter of each plant were prepared (to simulate the amount of fragments obtained per area by grinding the plants residue) and then packed in decomposition bags $(0.25 \times 0.23 \mathrm{~m})$ made of polyethylene, with a $4 \mathrm{~mm}$ mesh. Soon after sowing the cotton (December 18, 2012), six of those bags were distributed on the surface of the soil in each of the field plots of the cover plants. At 20, 50, 70, 110, 140, and 170 DAS of the cotton, one bag was collected from each plot (field $100 \mathrm{~m}^{2}$ ) and the plant residue it contained was manually cleaned, packed in a paper bag, and dried in an oven with forced air circulation, at $65^{\circ} \mathrm{C}$, until it achieved a constant weight, and the remaining dry matter was measured after that.

To describe the decomposition of the plant residues of cover crops, two models were adjusted: (i) the exponential model (EM), in which the remaining dry matter is used as the response variable, and (ii) the Michaelis-Menten model (MM), in which the dry matter already decomposed is used as the response variable.

The EM can be described as $D M_{r}=A \cdot e^{-k t}$, where $D M_{r}$ : remaining dry matter at the time t (in DAS); $A$ : dry matter at zero time. As the response variable adopted was the percentage of dry matter, and the readings, on each occasion, were taken as a proportion in relation to the known mass of initial dry matter, the considered parameter was $A=1$; $e$ : Napier's base or Euller number; $t$ : the number of days after sowing the cotton directly on the straw; $k$ : the constant of decomposition. The time required for $50 \%$ of the dry matter to be decomposed $\left(D M_{r}=0\right.$, $5 \mathrm{~A})$, called half-life time, was obtained by: $\mathrm{t}_{1 / 2}=\ln$ (2) $/ \mathrm{k}$.

In turn, the MM model can be described as $D M_{d}=A \cdot t /(V+t)$, where:

$D M_{d}$ : dry matter decomposed t days after the sowing of the cotton, which is equal to $1-D M_{r} ; A$ : in this case, A corresponds to the total decomposed ratio when $t$ tends to infinity. Assuming that all dry matter is decomposed, or at least almost totally decomposed during the cultivation cycle, we considered $A=1 ; \mathrm{V}$ : the parameter which estimate corresponds exactly to the half-life of the decomposition, i.e. the time for $50 \%$ of the dry matter to be decomposed.

For each one of the cover plants, there was an adjustment of the EM or MM models, adopting as a criterion the significance of the lack of adjustment of the regression. After identifying the best adjustment model for a given cover plant, an assessment was made on whether the parameters estimates of at least two cover plants could be described by a single estimate (REGAZZI; SILVA, 2010). All analyses were made by the statistical software R.

Table 1, adapted from Regazzi and Silva (2010), illustrates the decomposition of the degrees of freedom and the sums of squares for the variance analysis and for the regression analysis of non-linear models, according to a random blocks design.

Table 1. Scheme of the decomposition of the degrees of freedom (GL) and the sums of the square (SQ) pertaining to the sources of variation in the analysis of variance (ANOVA) and regression analysis (ANOVA regression).

\begin{tabular}{lcc}
\hline ANOVA & GL & SQ \\
\hline Block & $\mathrm{B}-1$ & $\mathrm{SQB}$ \\
Uncorrected treatment & $\mathrm{T}$ & $\mathrm{SQT}+\mathrm{C}$ \\
"Average" (Correction) & 1 & $\mathrm{C}$ \\
Treatments & $\mathrm{T}-1$ & $\mathrm{SQT}$ \\
Error (DBC) & $\mathrm{N}-\mathrm{B}-\mathrm{T}+1$ & $\mathrm{SQE}$ \\
\hline ANOVA Regression & $\mathrm{GL}$ & $\mathrm{SQ}$ \\
\hline Residues from the DIC Regression & $\mathrm{N}-\mathrm{p}$ & $\mathrm{SQRRDIC}$ \\
Residues from the DBC Regression & $\mathrm{N}-\mathrm{p}-(\mathrm{B}-1)$ & $\mathrm{SQRRDIC}-\mathrm{SQB}$ \\
Lack of DBC adjustment & $\mathrm{T}-\mathrm{p}$ & $\mathrm{SQRRDIC}-\mathrm{SQB}-\mathrm{SQE}$ \\
Regression parameters & $\mathrm{p}$ & $\mathrm{SQT}+\mathrm{C}-$ (SQRRDIC - SQB - SQE) \\
\hline
\end{tabular}

Source: adapted from Regazzi and Silva (2010).

$\mathrm{B}=$ number of blocks; $\mathrm{T}=$ number of treatments; $\mathrm{N}=$ number of plots; $\mathrm{p}=$ number of regression parameters;

$\mathrm{DIC}=$ analysis following an entirely random design; $\mathrm{DBC}=$ analysis following a random complete block design.

\section{RESULTS AND DISCUSSION}

Table 2 includes summaries of the variance and regression analyses for the three cover plants studied. Six decomposition bags with cover plants were lost, one on brachiaria, one on pigeon pea and four on millet. The source of variation from
"Treatments" (collection times) was significant for the three field trials, showing that the dry matter decomposition varied with time. The use of regression analysis is preferable for the quantitative factor, rather than the multiple comparison tests of means. 
Table 2. Estimates of the degrees of freedom (GL) and sums of squares (SQ) of the analysis of variance and regression analyses, considering adjustments to the Michaelis-Menten (MM) and exponential (EM) models, estimates of the parameters $\mathrm{V}$, for the MM model, and $\mathrm{k}$, for the EM model, obtained for each species.

\begin{tabular}{|c|c|c|c|c|c|c|c|c|c|}
\hline \multirow[t]{2}{*}{ ANOVA } & \multicolumn{3}{|c|}{----------Millet-------- } & \multicolumn{3}{|c|}{-----------Pigeon pea--------- } & \multicolumn{3}{|c|}{------Brachiaria------- } \\
\hline & GL & \multicolumn{2}{|c|}{ SQ ANOVA } & GL & \multicolumn{2}{|c|}{ SQ ANOVA } & GL & \multicolumn{2}{|c|}{ SQ ANOVA } \\
\hline Blocks & 3 & \multicolumn{2}{|c|}{0.029} & 3 & \multicolumn{2}{|c|}{0.197} & 3 & \multicolumn{2}{|c|}{0.057} \\
\hline Non-corrected treatment & 6 & \multicolumn{2}{|c|}{5.504} & 6 & \multicolumn{2}{|c|}{1.261} & 6 & \multicolumn{2}{|c|}{1.607} \\
\hline "Average" & 1 & \multicolumn{2}{|c|}{5.010} & 1 & \multicolumn{2}{|c|}{0.781} & 1 & \multicolumn{2}{|c|}{0.972} \\
\hline Treatments & 5 & \multicolumn{2}{|c|}{$0.494^{* *}$} & 5 & \multicolumn{2}{|c|}{$0.480^{* *}$} & 5 & \multicolumn{2}{|c|}{$0.634^{* *}$} \\
\hline Error (DBC) & 11 & \multicolumn{2}{|c|}{0.066} & 14 & \multicolumn{2}{|c|}{0.045} & 14 & \multicolumn{2}{|c|}{0.035} \\
\hline FV Regression & GL & SQMM & SQEM & GL & SQMM & SQEM & GL & SQMM & SQEM \\
\hline Residues from DIC Regression & 19 & 0.134 & 0.229 & 22 & 0.247 & 0.419 & 22 & 0.098 & 0.192 \\
\hline Residues from DBC Regression & 16 & 0.105 & 0.200 & 19 & 0.049 & 0.222 & 19 & 0.041 & 0.135 \\
\hline Lack of DBC adjustment & 5 & $0.040^{\mathrm{ns}}$ & $0.135^{*}$ & 5 & $0.004^{\mathrm{ns}}$ & $0.177^{* *}$ & 5 & $0.006^{\mathrm{ns}}$ & $0.100^{* *}$ \\
\hline Regression parameters & 1 & 5.464 & 5.369 & 1 & 1.257 & 1.084 & 1 & 1.601 & 1.507 \\
\hline Est. V (half-life 1/2 MM-days) & & 19.24 & - & & 49.82 & - & & 41.81 & - \\
\hline Estimate $\mathrm{k}$ & & - & 0.025 & & - & 0.0111 & & - & 0.0129 \\
\hline Half-life exponential (days) & & - & 27.8 & & - & 62.4 & & - & 53.7 \\
\hline
\end{tabular}

$\mathrm{ns}, * * *$ : lack of adjustment of the non-significant regression, significant at $5 \%$ and significant at $1 \%$, respectively, considering the MM and exponential models adjusted to each species.

For the three cover plants, the source of variation from "Lack of adjustment" was significant for EM and non-significant for the MM model. This indicates that the MM model had a better adjustment than EM, regardless of the cover plant considered. Therefore, for the conditions studied, we can see that the exponential model did not explain the dynamics of decomposition as regards to time, although this is the most common model for this type of study (TEIXEIRA et al., 2012; TORRES et al., 2015; COSTA et al., 2016).

It should be noted that $50 \%$ of the remaining dry matter or $50 \%$ of released dry matter is the same information described by different approaches. In both models, only one parameter was estimated, which, in this case, resulted in a more balanced comparison between them. The estimated half-life of EM was always higher than those of MM and consequently, overestimated (Table 2) at 9, 12 and 12 days for millet, pigeon pea, and brachiaria, respectively. Consequently, with the longer half-life of EM, the protection of the soil surface by the remaining straw is overestimated, and the mineralization of nutrients is underestimated. As such, based on studies for the selection of cover plants focused on a no-tillage system of cotton, the choice of any plant depending on the estimated half-life in the EM could bring the false impression of a longer period of straw persistence.

In the literature, half-life times were found to vary between 40 and 131 days for millet (TORRES et al., 2005; BOER et al., 2008; FERREIRA et al., 2010; PACHECO et al., 2011; TEIXEIRA et al., 2011; SORATTO et al, 2012; TEIXEIRA et al., 2012; COSTA et al., 2015), between 24 to 160 days for Urochloa ruziziensis (BELO et al., 2012; ROSSI et al., 2013; COSTA et al., 2014; SANTOS et al., 2014), and from 21 to 114 days for Cajanus cajan (TORRES et al., 2005; TORRES; PEREIRA, 2008; BELO et al., 2012). These discrepancies may be related to the use of cultivars with different potential for dry matter production, different chemical compositions, greater contact between the straw and the soil, and the combination of high temperatures and rainfall that influence the decomposition process. These variations in the half-life time may also be associated with the seeding times of cover plants and management of desiccation, which, when performed in the middle of the inter-crop season, usually results in a longer half-life of the residual dry matter (PACHECO et al., 2011; ROSSI et al., 2013).

After the superiority of the adjustment of the MM model in relation to the EM was confirmed, the equality of the "V" estimates for the half-life of cover plants was tested. A complete model was considered to be the one where a $\mathrm{V}$ estimate was necessary for each cover plant. Three reduced models were: 1) a single half-life estimate to explain the behavior of the three plants; 2) a common estimate for brachiaria and millet and another for pigeon pea and; 3) one estimate for millet and another common to brachiaria and pigeon pea 
(Table 3). The half-life time for brachiaria was intermediate to that of millet and pigeon pea, which is why a reduced model with an estimate of "V" for brachiaria and another common to pigeon pea and millet would not be relevant. All of the contrasts between each reduced model and the full model were significant, ruling out the possible invalidity that at least two of the cover plants evaluated would have a similar half-life, which would imply the need for adjustment of a decomposition curve for each species.

Table 3. Estimates of the half-life parameters $(\mathrm{V})$ for each species of the cover crops (millet $=\mathrm{Vm}$; brachiaria $=\mathrm{Vb}$, and pigeon pea $=\mathrm{Vg}$ ) in the reduced and complete models, and the respective sums of squares of the residues from the regression based on the model in DBC (SQRRDBC) and the sufficiency F-test of each reduced model versus the complete model.

\begin{tabular}{ccccc}
\hline Parameters & \multicolumn{2}{c}{------ reduced models $(\mathrm{mr})$} & complete model (mc) \\
& $\mathrm{Vm}=\mathrm{Vb}=\mathrm{Vg}$ & $\mathrm{Vm}=\mathrm{Vb}$ and $\mathrm{Vg}$ & $\mathrm{Vm}$ and $\mathrm{Vb}=\mathrm{Vg}$ & $\mathrm{Vm}, \mathrm{Vb}$, and $\mathrm{Vg}$ \\
\hline $\mathrm{Vm}$ & 35.5 & 29.5 & 19.2 & 19.2 \\
$\mathrm{Vb}$ & 35.5 & 29.5 & 45.6 & 41.8 \\
$\mathrm{Vg}$ & 35.5 & 49.8 & 45.6 & 49.8 \\
$\mathrm{SQRRDBC}$ & 0.598 & 0.430 & 0.212 & 0.196 \\
$\mathrm{~F}$ (mr vs. mc) & $55.36^{* *}$ & $64.5^{* *}$ & $4.3157^{*}$ & - \\
\hline
\end{tabular}

Figure 1 shows the adjusted curves according to the estimated "V" parameters, as well as the average values of the readings on each collection date for each species. The horizontal dashed lines indicate 50 and $75 \%$ of dry matter released. The $50 \%$ horizontal line intersects the curves at the points corresponding to the half-life of each species, illustrated by the vertical dashed lines to the respective interception points of the abscissa. The other vertical dashed lines indicate the number of days needed to decompose $75 \%$ of the dry matter for each cover plant. The slowest decomposition speed of pigeon pea probably occurred due to a higher concentration of recalcitrant aromatic compounds in the plant tissue, as verified by Carvalho et al. (2013) and Carvalho et al. (2014). Initially, the decomposition of the dry matter of plants involves the degradation of less stable compounds, such as cellulose and hemicellulose, and then the slow transformation of aromatic structures and recalcitrant carbon of lignified tissues (KÖGEL-KNABNER, 2000; CARVALHO et al., 2013). The brachiaria had a low half-life, as previously noted by Carvalho et al. (2013), who justified it by the low concentration of lignin and the lowest lignin: $\mathrm{N}$ ratio in the dry matter of the upper part of the plant.

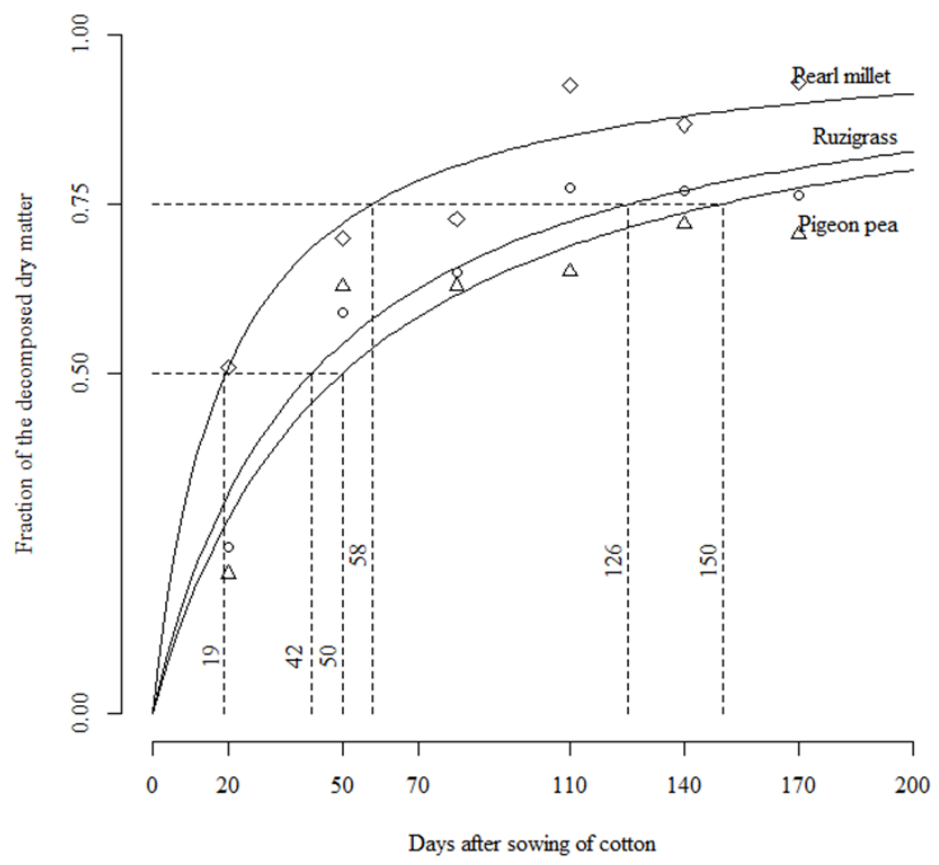

Figure 1. The fraction of dry matter decomposed for each cover plan based on the number of days after direct seeding of cotton on the straw and the respective times for decomposition of $50 \%$ (half-life) and $75 \%$ of the dry matter, according to the Michaelis-Menten model. 
As the MM model, for the three cover plants studied, presented a better adjustment than the EM, and this latter is the most widely used to explain the dynamics of decomposition of residual dry matter in terms of time, new studies with other cover plants grown in the "Cerrado" would be important, especially for no-tillage systems, where knowledge of the half-life of decomposition is an important factor for production system.

\section{CONCLUSION}

The decomposition of the dry matter of millet, brachiaria, and pigeon pea was not adequately explained by the adjustment of the exponential model, but was by the Michaelis-Menten model, with the first one overestimating the half-life time. The cover plants studied differed as to the speed of decomposition of dry matter, requiring a specific curve adjustment by the Michaelis-Menten model. Based on this model, the half-life time of millet, brachiaria, and pigeon pea was 19, 42, and 50 days, respectively.

\section{REFERENCES}

ACOSTA, J. A. A. et al. Decomposição da fitomassa de plantas de cobertura e liberação de nitrogênio em função da quantidade de resíduos aportada ao solo sob sistema plantio direto. Ciência Rural, Santa Maria, v. 44, n. 5, p. 801-809, 2014.

BELO, E. S. et al. Decomposição de diferentes resíduos orgânicos e efeito na atividade microbiana em um Latossolo Vermelho de Cerrado. Global Science and Technology, Rio Verde, v. 5, n. 3, p. 107-116, 2012.

BOER, C. A. et al. Biomassa, decomposição e cobertura do solo ocasionada por resíduos culturais de três espécies vegetais na região Centro-Oeste do Brasil. Revista Brasileira de Ciência do Solo, Viçosa, v. 32, n. 2, p. 843-851, 2008.

CARVALHO, A. M. et al. Chemical composition of cover plants and its effect on maize yield in notillage systems in the Brazilian savanna. Crop \& Pasture Science, Clayton, v. 63, n. 11-12, p. 1075 1081, 2013.

CARVALHO, A. M. et al. Characterization of cover crops by NMR spectroscopy: impacts on soil carbon, nitrogen and phosphorus under tillage regimes. Revista Ciência Agronômica, Fortaleza, v. 45, n. 5, p. 968-975, 2014.

COSTA, C. H. M. et al. Nitrogen fertilization on palisadegrass: phytomass decomposition and nutrients release. Pesquisa Agropecuária Tropical, Goiânia, v. 46, n. 2, p. 159-168, 2016.

COSTA, N. R. et al. Acúmulo de nutrientes e decomposição da palhada de braquiárias em função do manejo de corte e produção do milho em sucessão. Revista Brasileira de Ciências Agrárias, Recife, v. 9, n. 2, p. 166-173, 2014.

COSTA, N. R. et al. Acúmulo de nutrientes e tempo de decomposição da palhada de espécies forrageiras em função de épocas de semeadura. Bioscience Journal, Uberlândia, v. 31, n. 3, p. 818-829, 2015.

DERPSCH, R. et al. Current status of adoption of no -till farming in the world and some of its main benefits. International Journal of Agricultural and Biological Engineering, Beijing, v. 3, n. 1, p. 1$25,2010$.

ESPÍNDOLA, J. A. A. et al. Decomposição e liberação de nutrientes acumulados em leguminosas herbáceas perenes consorciadas com bananeira. Revista Brasileira de Ciência do Solo, Viçosa, v. 30, n. 2, p. 321-328, 2006.

FERREIRA, A. C. B. et al. Produção de biomassa por cultivos de cobertura do solo e produtividade do algodoeiro em plantio direto. Pesquisa Agropecuária Brasileira, Brasília, v. 45, n. 6, p. 546-553, 2010

FERREIRA, A. C. B. et al. Plantas que minimizam problemas do sistema de produção do algodoeiro no cerrado. Campina Grande: Embrapa Algodão, 2012. 4 p. (Comunicado Técnico 371).

KÖGEL-KNABNER, I. Analytical approaches for characterizing soil organic matter. Organic Geochemistry, The Hague, v. 31, n. 7, p. 609-625, 2000 .

MACHADO, E. J. Uso do 'Bootstrap' na estimação de parâmetros em modelos não lineares: uma aplicação em mecanismos cinéticos de Michaelis-Menten. 2006. 131 f. Dissertação (Mestrado em Agronomia: Área de Concentração em Estatística e Experimentação Agropecuária) Universidade Federal de Lavras, Lavras, 2006.

PACHECO, L. P. et al. Produção de fitomassa e acúmulo e liberação de nutrientes por plantas de cobertura na safrinha. Pesquisa Agropecuária Brasileira, Brasília, v. 46, n. 1, p. 17-25, 2011.

REGAZZI, A. J.; SILVA, C. H. O. Teste para verificar a igualdade de parâmetros e a identidade de modelos de regressão não-linear. I. Dados no delineamento inteiramente casualizado. Revista de Matemática e Estatística, São Paulo, v. 22, n. 3, p. 
$33-45,2004$.

REGAZZI, A. J.; SILVA, C. H. O. Testes para verificar a igualdade de parâmetros e a identidade de modelos de regressão não-linear em dados de experimentos com delineamento em blocos casualizados. Revista Ceres, Viçosa, v. 57, n. 3, p. 315-320, 2010.

ROSSI, C. Q. et al. Decomposição e liberação de nutrientes da palhada de braquiária, sorgo e soja em áreas de plantio direto no cerrado. Semina: Ciências Agrárias, Londrina, v. 34, n. 4, p. 1523-1534, 2013.

SANTOS, F. C. et al. Decomposição e liberação de macronutrientes da palhada de milho e braquiária, sob integração lavoura-pecuária no cerrado baiano. Revista Brasileira de Ciência do Solo, Viçosa, v. 38, n. 6, p. 1855-1861, 2014.

SORATTO, R. P. et al. Produção, decomposição e ciclagem de nutrientes em resíduos de crotalária e milheto, cultivados solteiros e consorciados. Pesquisa Agropecuária Brasileira, Brasília, v. 47, n. 10, p. 1462-1470, 2012.

SORENSEN, R.; NOVAK, N. The Use of Michaelis -Menten Kinetics in Cell Biology and Physiology Teaching Laboratories. Biochemical Education, Hoboken, v. 24, n. 1, p. 26-28. 1996.

TEIXEIRA, M. B. et al. Decomposição e liberação de nutrientes da parte aérea de plantas de milheto e sorgo. Revista Brasileira de Ciência do Solo, Viçosa, v. 35, n. 3, p. 867-876, 2011.

TEIXEIRA, M. B. et al. Decomposição e ciclagem de nutrientes dos resíduos de quatro plantas de cobertura do solo. Idesia, Arica, v. 30, n. 1, p. 55-64, 2012.

TORRES, J. L. R. et al. Decomposição e liberação de nitrogênio de resíduos culturais de plantas de cobertura em um solo de cerrado. Revista Brasileira de Ciência do Solo, Viçosa, v. 29, n. 4, p. 609-618, 2005.

TORRES, J. L. R. et al. Production, decomposition of residues and yield of maize and soybeans grown on cover crops. Revista Ciência Agronômica, Fortaleza, v. 46, n. 3, p. 451-459, 2015.

TORRES, J. L. R.; PEREIRA, M. G. Dinâmica do potássio nos resíduos vegetais de plantas de cobertura no Cerrado. Revista Brasileira de Ciência do Solo, Viçosa, v. 32, n. 4, p. 1609-1618, 2008.

ZEVIANI, W. M. et al. Modelos não lineares para a liberação de potássio de estercos animais em latossolos. Ciência Rural, Santa Maria, v. 42, n. 10, p. 1789-1796, 2012. 